Staging the Gaze 



\section{Staging the Gaze}

POSTMODERNISM, PSYCHOANALYSIS, AND SHAKESPEAREAN COMEDY

\section{Barbara Freedman}

Cornell University Press

ITHACA AND LONDON 
Copyright (C) I99 I by Cornell University

All rights reserved. Except for brief quotations in a review, this book, or parts thereof, must not be reproduced in any form without permission in writing from the publisher. For information, address Cornell University Press, I 24 Roberts Place, Ithaca, New York 14850.

First published I99I by Cornell University Press.

International Standard Book Number 0-80 14-2279-5 (cloth) International Standard Book Number 0-8014-9737-X (paper)

Library of Congress Catalog Card Number 90-55I I 7

Printed in the United States of America

"Keeping Things Whole" is reprinted with permission of Atheneum Publishers, an imprint of Macmillan Publishing Company, from Reasons for Moving by Mark Strand. Copyright (C) 1964 by Mark Strand.

Librarians: Library of Congress cataloging information appears on the last page of the book.

@The paper in this book meets the minimum requirements of the American National Standard for Information SciencesPermanence of Paper for Printed Library Materials, ANSI Z39.48-I984.

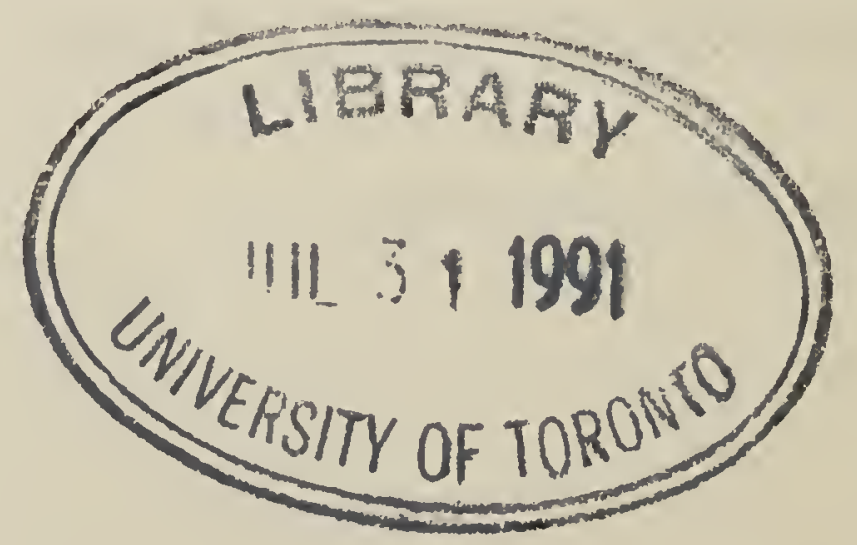


For Paul 
In a field

I am the absence

of field.

This is

always the case.

Wherever I am

I am what is missing.

When I walk

I part the air

and always

the air moves in

to fill the spaces

where my body's been.

We all have reasons

for moving.

I move

to keep things whole.

-Mark Strand, "Keeping Things Whole" 